九州大学学術情報リポジトリ

Kyushu University Institutional Repository

Comparison of Body Weight Changes between Sexes and among Differences in Litter Composition during Suckling Period in Kids of Tokara Native Goats

Bungo, Takashi

Laboratory of Animal Feed Science, Faculty of Agriculture, Kyushu University

Nishimura, Shotaro

Laboratory of Functional Anatomy of Domestic Animals, Faculty of Agriculture, Kyushu University

Nakano, Yutaka

Kyushu University Farm

Okano, Kaoru

Kyushu University Farm

他

https://doi.org/10.5109/24312

出版情報：九州大学大学院農学研究院紀要. 44 (1/2)，pp. 105-109，1999-11. Kyushu University バージョン：

権利関係 : 


\title{
Comparison of Body Weight Changes between Sexes and among Differences in Litter Composition during Suckling Period in Kids of Tokara Native Goats
}

\author{
Takashi Bungo, Shotaro Nishimura*, Yutaka Nakano**, Kaoru Okano**, \\ Hirotoshi Furusawa**, Masataka Shimojo, Mitsuhiro Furuse, \\ Yasuhisa Masuda and Ichiro Goto***
}

Laboratory of Animal Feed Science, Faculty of Agriculture, Kyushu University, Fukuoka 812-8581, Japan

(Received July 2, 1999 and accepted August 24, 1999)

\begin{abstract}
Data on body weight changes in kids of Tokara native goats were collected from 68 kids (13 male singles, 11 female singles, 10 sets of male twins, 4 sets of female twins and 8 sets of male-female twins) during the 10-week suckling period. Each kid or set of twins was housed with corresponding mother and kid(s)-mother pairs were housed separately each other. Kids were weighed from the birth of life to 10 weeks of age at two-week intervals. The body weight, of male kids was significantly higher than that of female kids during the period. In male kids, the body weight of the male in male-female twins was the highest from the birth to the 6 th week of age, but male singles showed the highest body weight after the 8 th week and male twins tended to show the lowest body weight during the period. In female kids, the body weight of the fermale in male-female twins was the highest and that in female twins were the lowest during the period. It was suggested that (1) male kids showed slightly higher growth rate than female kids and this was due to higher activity in the milk sucking, and (2) the male sib accelerated the growth rate of the female in male-female twins through stimulating the milk sucking.
\end{abstract}

\section{INTRODUCTION}

Goats, as well as sheep, are one of the important farm animals in Asian countries in the subtropical and tropical regions. Growing kids healthily up to be mature is indispensable to the goat farming. The basic method for the health care of individual animals is measuring and recording their body weights. The body weight measurement at regular intervals is useful for the decision of weaning time in kids and lams (Villegas, 1939) and in lambs (Brown, 1964). In addition, there are some studies with lambs regarding the growth as a sequence of events that has already started before birth (Wallace, 1948; Burfening, 1972).

In Japan Tokara native goats are considered available as one of the experimental animals for not only goat production but also the production of other farm ruminant animals. However, only few reports have so far been made on Tokara native goats (Manda, 1986, Okano et al., 1991), and no reports have ever tried to describe body weight changes of kids during the suckling period in relation to litter composition. The purpose

\footnotetext{
* Laboratory of Functional Anatomy of Domestic Animals, Faculty of Agriculture, Kyushu University, Fukuoka 812-8581, Japan

** Kyushu University Farm, Fukuoka 811-2307, Japan

*** Lniversity of the Air, Fukuoka Study Center, Fukıoka 812-0016
} 
of this report was to compare body weight changes during the suckling period between sexes and among differences in litter composition in kids of Tokara native goats.

\section{MATERIALS AND METHODS}

Sixty-eight pre-weaning kids of Tokara native goats produced at the Kyushu University Farm were used. The kids were romposed of 13 male singles, 11 female singles, 10 sets of male twins, 4 sets of female twins and 8 sets of male-female twins. There were, therefore, five categories.

Each kid or set of twins with corresponding mother was housed together in a pen and kid(s)-mother pairs were housed separately each other. Each pen had an area of $2.24 \mathrm{~m}^{2}$ $(1.6 \mathrm{~m} \times 1.4 \mathrm{~m})$ and was bedded with sawdust, rice husks and straw. Animals were allowed to eat Italian ryegrass hay ad libitum and $100 \mathrm{~g} / \mathrm{pen} /$ day of concentrate with free access to water and a mineral lick.

Kids were weighed from the birth to 10 weeks of age at two-week intervals, but at every measurement of body weight a few kids that were not particular ones did not join. From these data, the mean value of body weights in each category was calculated at every 2 weeks. In addition, differences in the mean body weight between categories were tested for significance using Fisher's protected LSD test.

\section{RESULTS AND DISCUSSION}

\section{Comparison of growth between male and female kids}

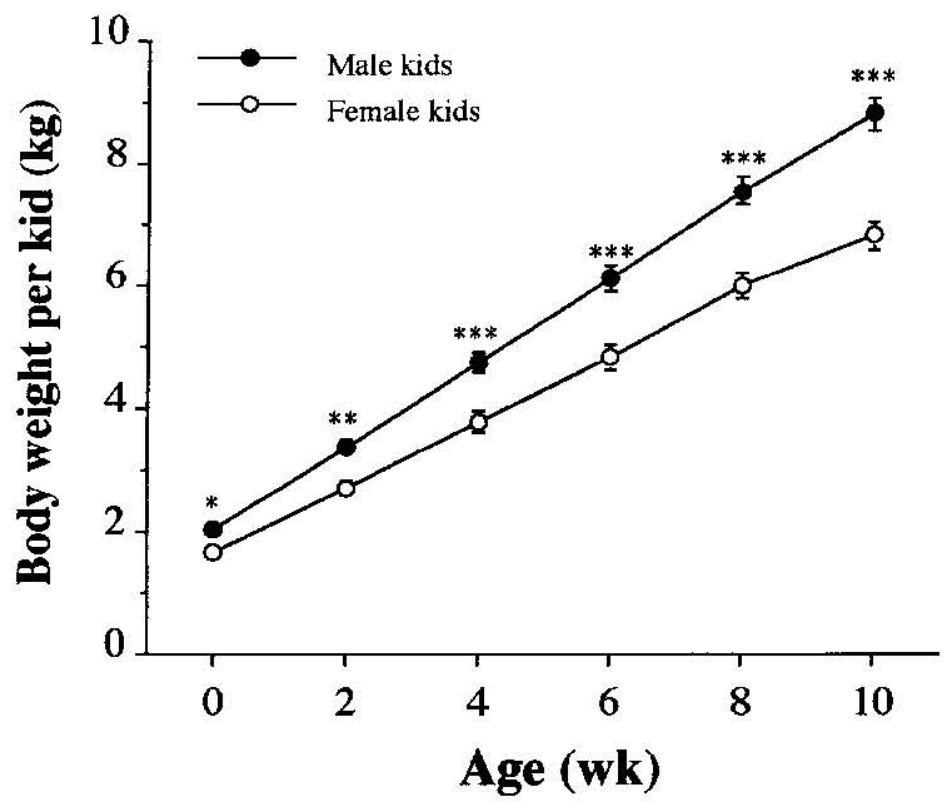

Fig. 1. Changes in body weights of male and female kids in Tokara native goats during the suckling period $\left({ }^{*} \mathrm{P}<0.05\right.$, $\left.{ }^{*} \mathrm{P}<0.01,{ }^{* * *} \mathrm{P}<0.001\right)$. 
Figure 1 shows changes in body weights of male and female kids during the suckling period. Birth weights of male and female were $2.05 \mathrm{~kg}$ and $1.67 \mathrm{~kg}$, respectively, and male was heavier than female $(\mathrm{P}<0.05)$. Manda $(1986)$ reported that birth weights for male and female were 1.5 and $1.4 \mathrm{~kg}$, respectively. Our report showed slightly heavier birth weights compared with those reported by Manda (1986). The birth weight difference between male and female kids was larger in the present report than in the report of Manda (1986). The tendency in which male was heavier than female continued at subsequent weeks of age and there were significant differences at 2 weeks $(\mathrm{P}<0.01)$ and $4 \sim 10$ weeks $(\mathrm{P}<0.001)$. Body weight differences between male and female increased gradually due to the higher rate of male growth than that of female growth. This is similar to the report by Manda (1986) of Tokara native goats and is also observed for goats and sheep (Villegas, 1939) and for sheep (Brown, 1964) of other breeds.

\section{Comparison of growth among differences in litter composition in male kids}

Changes in body weight of male singles, male twins and the male in male-female twins were shown in Table 1 . The body weight difference between male singles and male twins tended to become larger gradually through the suckling period, though there were not significant differences. The amount of milk supplied from mother affects the growth of kids. Milk should be shared between twins, even if there is higher frequency of sucklings for twins than for singles (Ewbank, 1964) and the share of milk would be the same between male twins. This might cause slightly higher body weight in male singles compared with male twins. The body weight of the male in male-female twins was slightly higher than that of male twins during the period except for the 8 th week of age, though no significant differences were shown. This seems to be due to more active sucking behavior in male kids compared with female kids (Clutton-Brock et al., 1982), resulting in that the male could acquire more milk than his share in male-female twins. The body weight of the male in male-female twins was slightly higher than that of male singles from the birth to the 6 th week of age, though there were not significant differences. This seems to be due to higher frequency of sucklings for twins than for singles (Ewbank, 1964) and to sucking more milk than his share by the male in male-female twins. However, after the 8 th week the value turned to be higher in male singles compared with the male in male-female twins. This might be caused by more

Table 1. Changes in body weight per kid of male singles, male twins and the male in male-female twins during the suckling period.

\begin{tabular}{|c|c|c|c|}
\hline \multirow{2}{*}{ Age } & Male singles & Male twins & Male in male-female twins \\
\hline & (N) BW $(\mathrm{kg}) \pm S D$ & (N) BW (kg) $\pm \mathrm{SD}$ & (N) BW $(\mathrm{kg}) \pm \mathrm{SD}$ \\
\hline Birth & (4) $2.10 \pm 0.43$ & (16) $2.01 \pm 0.40$ & (3) $2.13 \pm 0.25$ \\
\hline 2 nd week & (9) $3.46 \pm 0.49$ & (16) $3.26 \pm 0.74$ & (5) $3.65 \pm 0.42$ \\
\hline 4 th week & (8) $4.79 \pm 0.92$ & (14) $4.66 \pm 0.97$ & (5) $4.96 \pm 0.67$ \\
\hline 6 th week & (9) $6.32 \pm 1.23$ & (16) $5.95 \pm 1.21$ & (3) $6.45 \pm 0.95$ \\
\hline 8 th week & (10) $7.94 \pm 1.45$ & (18) $7.48 \pm 1.30$ & (7) $7.25 \pm 0.82$ \\
\hline 10 th week & (10) $9.26 \pm 1.72$ & (16) $8.56 \pm 1.67$ & (6) $8.77 \pm 0.95$ \\
\hline
\end{tabular}


ingestion of milk in male singles compared with the male in male-female singles. There would have occurred the start of rejection to nurse and the reduction of milk secretion, which might give more profits to male singles from their situation of only kid, when compared with the male in male-female twins even if he got more milk than his share.

\section{Comparison of growth among differences in litter composition in female kids}

Changes in body weight of female singles, female twins and the female in male-female twins are shown in Table 2 . The body weight was slightly higher in female singles than in female twins during the suckling period, though there were not significant differences. This seems to be due to sucking more milk in female singles compared with female twins, which is like the situation of male kids (Table 1). The body weight of the female in male-female twins was slightly higher than that of female twins during the period with significant differences $(\mathrm{P}<0.05)$ from the 2 nd to the 6 th week of age. This seems to come from that (1) twins are usually suck at the same time (Hulet et al., 1981), therefore, (2) the female in male-female twins, when compared with female twins, would show more active sucking according to the activation by the presence of the male sib that is usually more active in sucking than female (Clutton-Brock et al., 1982). The body weight of the female in male-female twins was slightly higher than that of female singles during the period, though no significant differences were shown. The reason for this seems to be due to higher frequency of sucklings for twins than for singles (Ewbank, 1964) and more active sucking by the presence of the male sib in male-female twins compared with female singles. Higher body weight for the female in male-female twins than for female singles even after the 8 th week of age seems, unlike the corresponding case of male kids (Table 1), to be caused by the later occurrence of the rejection to nurse by mother goats against female kids than against male kids (Clutton-Brock, 1991).

In the present study the body weight difference between male and female kids has been mainly ascribed to the difference in milk sucking activity. The present subject should be examined in future studies from the viewpoint of differences in other physiological conditions between male and female kids.

Table 2. Changes in body weight per kid of female singles, female twins and the fermale iл male-female twins during the suckling period.

\begin{tabular}{|c|c|c|c|}
\hline \multirow{2}{*}{ Age } & Female singles & Fernale twins & Female in male-female twins \\
\hline & $(\mathrm{N}) \mathrm{BW}(\mathrm{kg}) \pm \mathrm{SD}$ & (N) BW (kg) $\pm \mathrm{SD}$ & (N) BW (kg) \pm SD \\
\hline Birth & (7) $1.67 \pm 0.44$ & (6) $1.51 \pm 0.28$ & (3) $1.97 \pm 0.15$ \\
\hline 2 nd week & (11) $2.77 \pm 0.50^{\text {al }}$ & (6) $2.17 \pm 0.25^{\mathrm{b}}$ & (5) $3.20 \pm 0.43^{a}$ \\
\hline 4 th week & (9) $3.83 \pm 0.73^{\mathrm{ab})}$ & (6) $3.22 \pm 0.52^{b}$ & (5) $4.43 \pm 0.67^{a\}}$ \\
\hline 6 th week & (9) $4.95 \pm 0.84^{\text {abl }}$ & (4) $3.83 \pm 0.33^{\mathrm{b}}$ & (3) $5.88 \pm 0.70^{n)}$ \\
\hline 8 th week & (8) $6.14 \pm 0.88$ & (6) $5.32 \pm 0.78$ & (7) $6.39 \pm 0.97$ \\
\hline 10 th week & (9) $6.75 \pm 1.14$ & (6) $6.45 \pm 0.95$ & (6) $7.32 \pm 0.99$ \\
\hline
\end{tabular}

Mean values with different superscript letter were significantly different: $\mathrm{P}<0.05$ 


\section{Conclusions}

It was suggested from the present report with kids of Tokara native goats that (1) male kids showed slightly higher rate of growth than female kids and this was due to higher activity in the milk sucking by male kids, and (2) the presence of male sib accelerated the growth rate of the female in male-female twins through stimulating the milk sucking.

\section{REFERENCES}

Brown, T. H. 1964 The early weaning of lambs. J. Agric. Sci., Camb., 63: 191-204

Burfening, P. .J. 1972 Prenatal and postnatal competition among twin lambs. Anim. Prod., 15: 61-66

Clutton-Brock, T. H., Guinness, F. E. and Albon, S. D. 1982 Red deer. The University of (Chicago Press, Chịcago.

Clutton-Brock, T. H. 1991 Parent-offspring conflict. In "The evolution of parental care", pp. 193-207 Princeton University Press, New Jersey.

Ewbank, R., 1964. Observations on the suckling habits of twin lambs. Anim. Behav., 12: 34-37

Hulet, C. V., Alexander, G. and Hafez, E. S. E. 1981 The behaviour of sheep. In "The Behaviour of Domestic Arimals (3rd ed.)", ed by E. S. E. Hafez, Bailliere Tindall, London, pp. 246-294

Manda, M. 1986 Availability of Tokara goats for laboratory animals. Experimental Herbivore. 11: 84-95 (in Japanese)

Okano, K., Bungo, T., Yamada, S., Furusawa, H., Fukutome, T. and Kamohara, M. 1991 Changes in body weight of Tokara native goats from birth to the 1st year of age. Kyushu Univ. Farm Rep., 13: 38-39 (in Japanese)

Villegas, V. 1939 Multiple births in goats and sheep. Philippine Agric., 28: 5-14

Wallace, L. R. 1948 The growth of lambs before and after birth in relation to the level of nutrition. $J$ Agric. Sci. Camb., 38: 93-153 